\title{
Anticipační načasování riternu na základě odhadu dráhy letu míče
}

\section{Return temporal anticipation on the basis of the ball trajectory estimation}

\author{
Jan Carboch, František Lopot, Vladimír Süss, Tomáš Kočíb \\ Fakulta tělesné výchovy a sportu Univerzity Karlovy v Praze
}

\begin{abstract}
Abstrakt
Odehrání míče v tenise vyžaduje především prostorově-časovou informaci o dráze letu miče. Ve výzkumu jsme se zaměrili na časovou složku při riternu. Pomocí nahrávacího stroje jsme simulovali podání soupeře. Testované osoby měly na hlavě okluzní brýle Plató, které jim při nahrání míče z nahrávacího stroje zatemnily vidèní na určitou dobu. Předem neznaly ani rychlost letícího míče, ani část dráhy jeho letu, která bude zatemnèna. Zkoumali jsme pomocí okluzních brýlí vliv zatemnění určitých částí dráhy letu míče na načasování odehrání míče při riternu. Analýza nám ukázala, že největši problémy nastávaly při absenci informace o druhé třetině dráhy letu miče, $k d y$ testované osoby dosahovaly největš́ho počtu časových chyb.
\end{abstract}

\begin{abstract}
Ball-hitting in tennis involves spatio-temporal information about the ball's flight trajectory. We have focused on the temporal part of the information during returning a tennis serve that was simulated by a ball machine. The tested people had occlusion glasses placed on their eyes, which occluded their vision at the exact time, when the ball was being sent from the ball machine. The tested person did not know which part of the ball flight trajectory would be occluded, nor the ball speed. We examined the effect of part ball flight trajectory occlusion on the correct return timing of the ball. The analysis revealed that the greatest problems occurred while the second third of the ball flight trajectory had been occluded and reached most temporal errors at that time.
\end{abstract}

Klićcová slova: $\quad$ tenis, dráha letu míče, ritern, okluzní brýle

Keywords: $\quad$ tennis, ball flight trajectory, return stroke, occlusion glasses

Výstup vznikl za podpory specifického výzkumu 2010-261601, Výzkumného zámèru MŠMT ČR MSM 0021620864 a firmy Wilson.

\section{ÚVOD}

Předpokladem úspěšného odehrání míče $\mathrm{v}$ tenisu je včasné postavení hráče na optimální místo na dvorci. Podle Schmidta (1991) kladou dovednosti v tenise důraz na smyslově percepční faktory. Mají jak prostorové, tak časové cíle, které jsou složitě zkombinované. Zasáhnout míč letící od soupeře vyžaduje trojí přesnost: prostorovou přesnost (kde švihnout, aby byl míč zasažen), časovou (kdy švihnout) a načasování doby trvání vlastního švihu. Anticipace minimalizuje dobu prodlení. Lze tedy říci, že úloha hráče, na něhož letí soupeřův míč, zahrnuje tyto procesy: anticipaci a načasování, predikci dráhy letu míče v prostoru a okamžik dosažení kontaktu s raketou.

Studie (Abernethy a Zawi, 2007; Allard a Starkes, 1980; Shim et al., 2005a; Shim et al., 2006) zabývající se problematikou anticipace byly zaměřeny především na laboratorně založené prrístupy, které probíhaly pomocí zatemňování částí na prezentacích či filmových ukázkách na obrazovce. Shim et al. (2005) tvrdí, že je možné anticipovat typ úderu, nikoli však jeho směr. V rychlých sportovních hrách, jako je tenis, je potřeba převážně ignorovat právě zobrazenou herní strukturu, a zaměřit se především na rozpoznání pozice míče (Williams et al. 1999). Laboratorní studie nedovoluje, jelikož při tachistoskopických prezentacích nelze použít podstatné související vzory, aby se přesněji anticipoval př́let míče.

V terénních přístupech (Rippol, 1989; Singer et al., 1998) bylo zkoumáno přístrojem, na co přesně se zaostřují oči testovaných osob během anticipování pohybu soupeře. Jiné studie sledovaly pomocí zatem- 
nění vidění v době zásahu soupeře, jak dokáže odhadnout hráč typ úderu soupeře (Day, 1980). Většina všech př́stupů je zaměřena převážně na anticipaci technickou, tzn. jak odhadne hráč následující typ úderu soupeře před zásahem míče. Williams et al. (1999) ř́ká, že na tuto hlubokou predikci se dá více spolehnout, než na informace během počátečních částí letu míče.

Avšak pro hráče tenisu je důležitá informace o dráze letu míče. Studie zabývající se anticipací po zásahu míče soupeřem se zaměřují především na anticipaci prostorovou, kde se snaží určit místo dopadu míče ve hřišti (Féry, 2001; Williams, 1994) či místo v prostoru, kde zasáhnout míč (Crognier, 2005). Perceptivní anticipace je schopnost předvídat podle různých informací (Crespo a Miley, 2002; Poulton, 1957). Glencross a Cibich (1977) tvrdí, že perceptivní anticipace je podstatná ve sportu, protože vrozené limitace člověka v reakční době a době pohybu by měly za výsledek, že rozhodnutí by bylo uděláno př́liš pozdě pro účinnou protiakci. Williams (1994) pak při výzkumu, kdy hráči odhadovali dráhu letu míče a místo dopadu, poukazuje na menší čas strávený u expertů pozorováním míče, kde v tomto čase dokážou sledovat činnost soupeře.

Pro nás je podstatná perceptivní anticipace, což je vlastně odhad dráhy letu míče. Tento typ anticipace se uplatňuje po odehrání míče soupeřem. Hráč sleduje rychlost, výšku, směr a rotaci letícího míče. Rovněž musí vzít v úvahu podmínky, prostředí i povrch dvorce. Přijímajícímu hráči trvá 0,2 sekundy, než odhadne dráhu letu míče (Crespo a Miley, 2002).

Výzkumy zaměřené na zachycení letícího předmětu se vyskytují především ve formách chytání míče, kde se sleduje včasný stisk prstů (Dessing et al., 2008; Eliot et al., 1994). V laboratorním prostředí se pak snažily osoby o zachycení bodu střetu na obrazovce s pohybujícím se předmětem za různých vizuálních podmínek (Port et al., 1997). Bahill a LaRitz (1984) zjistili, že hráči nejsou schopni sledovat míč během celého jeho letu vzhledem k vizuálním omezením. Rovněž tvrdí, že i ti nejlepší sportovci nejsou schopni sledovat rychlý míč, který je blíže než $1,5 \mathrm{~m}$.

Pokud tedy hráči nepotřebují vidět celý let míče, naskytuje se otázka, zdali existuje nějaký úsek dráhy letu míče, který je zcela nezbytný pro posouzení dráhy letu míče, a který nikoliv, kdy se mohou hráči zaměřit na ostatní vizuální informace z okolního prostředí, jako je např́iklad pohyb či pozice soupeře. Výzkumy zabývající se důležitostí specifických úseků dráhy letu míče přinesly protichůdné výsledky. Např. Carlton (1981) zjistil, že zrak je zaměřen na letící objekt pouze v poslední polovině, kdy se blížící objekt nachází nedaleko cíle. Oproti tomu Haller a Clerk (1990) uvádějí, že pálkaři v baseballu využívají pouze velmi malou informaci během prostřední fáze letu míče, zatímco první a poslední ćást dráhy letu míče poskytují nezbytné informace pro přesný hráčův švih. Při výzkumu zkušených pálkařů však DeLucia a Cochran (1985) došli $\mathrm{k}$ tomu, že informace pro zásah míče může být získána $\mathrm{z}$ jakékoli části dráhy letu míče. Haller a Clark (1990) uvádějí, že zatemnění vidění méně zkušeným hráčủm těsně před chycením míče může ovlivnit jejich pozici ruky pro chycení - prostorovou přesnost. Avšak zkušení chytači nebyli ovlivnění tímto efektem a rovněž dokázali přesněji určit letové charakteristiky míče z dřívějších fází dráhy letu míče a následně využít tyto informace pro určení přesného bodu kontaktu. Okluzní brýle Plató nám umožní přesně zakrývat části letu míče, a tak určit vliv této proměnné na zásah míče.

\section{CÍL}

Cílem výzkumu bylo zjistit, jaké vizuální informace o dráze letu míče jsou pro hráče tenisu nejdůležitější, aby mohl správně načasovat úder a odehrát míč.

\section{SLEDOVANÝ SOUBOR}

Výzkumný soubor tvořili hráči tenisu mužské kategorie $(\mathrm{N}=20)$ s průměrným věkem 24 let $(\mathrm{SD}=$ 3,12 ) hrající pravou rukou, bez korekce vidění, ve věku 18-35 let a umístění do 200. místa na celostátním žebřičku v ČR.

\section{METODY}

Jednalo se o vnitroskupinový experiment, kde byl hodnocen zásah míče osobou v 6 různých podmínkách vyplývajících z kombinace 2 faktorů: rychlost letu míče a zatemnění vidění $(2 \times 3)$. Míć létal 
v průměrech dvou rychlostí přibližně $100 \mathrm{~km} / \mathrm{h}$ a $125 \mathrm{~km} / \mathrm{h}$, kdy testovaná osoba mohla vidět letící míč za plného vidění přibližně $1260 \mathrm{~ms}$ při rychlosti $100 \mathrm{~km} / \mathrm{h}$, a př̀ibližně $990 \mathrm{~ms}$ při rychlosti $125 \mathrm{~km} / \mathrm{h}$. Rychlost každého pokusu s maximálním rozpětím $5 \mathrm{~km} / \mathrm{h}$ byla kontrolována radarem. Zatemněna byla vždy jen jedna třetina dráhy letu míče, pokaždé s nastaveným zpožděním 0,2 s pro všechny pokusy. Např. při zatemnění první třetiny dráhy letu míče účastník vždy viděl $0,2 \mathrm{~s}$ míč a pak teprve došlo k zatemnění. Načasování třetin zatemnění vycházelo $\mathrm{z}$ časového údaje doby letu do místa kontaktu s raketou pro danou rychlost, zjištěnou v pilotní studii, minus $0,2 \mathrm{~s}$ zpoždění. Tento čas byl rozdělen na třetiny, které omezovaly vidění.

Testované osoby dostaly instrukce hrát úder plným švihem, nikoli pouze nastavit raketu, a mířit do určité pozice ve dvorci podél čáry, kde byl umístěn terč. Každý účastník dostal tři cvičné pokusy. Přibližně $0,5-1,5 \mathrm{~s}$ před každým výstřelem byla testovaná osoba upozorněna slovním signálem „akce“, že dojde $\mathrm{k}$ vystřelení míče $\mathrm{z}$ nahrávacího stroje poté, co pomocník vhodil míč do nahrávacího stroje. Následně bylo nahráno 5 míčů při rychlosti $100 \mathrm{~km} / \mathrm{h}$ a 5 míčů při rychlosti $125 \mathrm{~km} / \mathrm{h}$, bez jakéhokoliv zatemnění. Dále bylo nahráno 30 míčů. 5 opakování pro každou kombinaci 2 faktorů, kdy testované osoby nevěděly, jaká bude rychlost míče, ani jaká třetina dráhy letu míče bude zatemněna. Pořadí bylo uspořádáno náhodně. Po odehrání míče se hráč vrátil na výchozí pozici a čekal na další míč. Po 10 pokusech následovala vždy tříminutová přestávka.

Výzkum probíhal na krytém dvorci, aby nedocházelo $k$ vnějším nežádoucím vlivům (vítr, déšt apod.). Nahrávací stroj simulující podání soupeře byl umístěn na základní čáře, $1 \mathrm{~m}$ vpravo od stř̌ední čáry pro podání na tenisovém dvorci a ve výšce $2,8 \mathrm{~m}$ s výpustí míčů. Byl kalibrován, aby míče pokaždé letěly ve stejném směru do vymezeného pole, do forhendového úderu testovaných osob. V pozadí nahrávacího stroje byla umístěna tmavě zelená plachta. Testovaná osoba měla předem určenou výchozí pozici pro každý pokus $0,5 \mathrm{~m}$ za základní čarou a $0,7 \mathrm{~m}$ vlevo od podélné čáry pro dvouhru v pravé části dvorce. Testovaná osoba měla na hlavě brýle s tekutými krystaly Plató (Translucent Technologies), které se na základě impulsu fotodiody umístěné v hlavni nahrávacího stroje při průletu míče a nastavení času v počítači zatemnily na určitou dobu. Kamera byla umístěna zhruba $7 \mathrm{~m}$ od testované osoby vpravo v úrovni základní čáry.

Vyhodnocení dat proběhlo pomocí $2 \mathrm{D}$ analýzy. Nejprve jsme určili pro každou rychlost $(100 \mathrm{~km} / \mathrm{h}$ a $125 \mathrm{~km} / \mathrm{h}$ ) základní bod zásahu pro každého hráče. Ten byl určen $\mathrm{v} \mathrm{cm}$ na ekviintervalové škále pozicí zápěstí pravé ruky při kontaktu rakety s míčem vůči pupíku v horizontální ose. Z 5 pokusů pro každou rychlost byl určen pomocí mediánu bod, který se stal výchozím s hodnotou 0 pro ostatní pokusy se zatemněním vidění. Pokud pozice zápěstí při zásahu rakety s míčem byla před tímto výchozím bodem (hráč zasáhl míč př́liš brzy), hráč získal záporné hodnoty v cm na ekviintervalové škále, pokud za tímto bodem, hodnoty kladné. Výsledky jsou rozděleny do tří kategorií. 1) Zásah či minutí míče. 2) Zásah míče, ale v neobvyklé pozici, tzn., že hráč sice kontaktoval míč, avšak raketa se nacházela v nezvyklé pozici vůči ostatním segmentům těla (např. i když pozice zápěstí byla $\mathrm{v}$ dobré poloze blízko základního bodu, tak hlava rakety byla stále za hráčovým tělem, a tak se jednalo o špatné načasování úderu, bylo př́liš opožděné. Tatáž situace byla i naopak, když pozice hlavy rakety byla daleko před zápěstím a načasování úderu bylo př́liš brzké). 3) Správný zásah míče.

Všechny nahrávky byly znovu přehrány a bylo provedeno expertní hodnocení ke dvěma situacím třemi nezávislými hodnotiteli, kterým byly dány stejné instrukce a kritéria, jak posuzovat.

1. Každé minutí míče bylo posouzeno, zdali se jednalo o časovou chybu, tj. jestli testovaná osoba provedla úder př́liš brzy, či př́liš pozdě; nebo zdali se jednalo o chybu prostorovou. Shoda mezi třemi nezávislými hodnotiteli dosáhla 93,5\%.

2. Každý zásah míče byl hodnocen ve smyslu správný zásah, nebo zásah v neobvyklé pozici. Shoda mezi hodnotiteli byla $96,4 \%$.

\section{VÝSLEDKY}

Z 600 nahraných míčů jich nebylo zasaženo 77 (12,8 \%), z toho 40 při rychlosti $100 \mathrm{~km} / \mathrm{h}$ a 37 při rychlosti $125 \mathrm{~km} / \mathrm{h}$. Při analýze jednotlivých rychlostí a fází zatemnění (Tab. 1) zjistíme, že časových chyb 
$\mathrm{Xb}$ (úder proveden př́liš brzy) a Xp (úder proveden př́liš pozdě) bylo při rychlostech $100 \mathrm{~km} / \mathrm{h}$ i 125 $\mathrm{km} / \mathrm{h}$ nejvíce při zakrytí druhé tř̀etiny dráhy letu míče, 70,1 \% ze všech minutých míčů. Prostorové chyby v úderu zaujímaly $18,2 \% \mathrm{z}$ minutých míčů. Při tom bylo dosaženo podobného počtu chyb při obou rychlostech.

Tabulka 1 Srovnání časových a prostorových chyb při minutí míče v jednotlivých situacích

\begin{tabular}{|c|c|c|c|c|c|c|}
\hline & \multicolumn{3}{|c|}{$100 \mathrm{~km} / \mathrm{h}$} & \multicolumn{3}{c|}{$125 \mathrm{~km} / \mathrm{h}$} \\
\hline & 1. třetina & 2. třetina & 3. třetina & 1. třetina & 2. třetina & 3. třetina \\
\hline $\mathrm{Xb}$ & 4 & 27 & 0 & 0 & 2 & 0 \\
\hline $\mathrm{Xp}$ & 0 & 1 & 0 & 5 & 24 & 0 \\
\hline $\mathrm{X}$ & 0 & 6 & 2 & 3 & 2 & 1 \\
\hline
\end{tabular}

Zasažených míčů v neobvyklé pozici z 600 bylo 68 (11,3\%), z toho 18 při rychlosti $100 \mathrm{~km} / \mathrm{h}$ a 50 při rychlosti $125 \mathrm{~km} / \mathrm{h}$. K nejvíce př́padům docházelo (Tab. 2) při zatemněné druhé třetině dráhy letu míče, celkem 79,4\%. V 72,1 \% hráč provedl švih opožděně (P), v 17,9\% př́liš brzy (B). Více těchto neobvyklých pozic se vyskytlo při vyšší rychlosti $125 \mathrm{~km} / \mathrm{h}(73,5 \%)$.

Tabulka 2 Srovnání zásahu míče v neobvyklé pozici

\begin{tabular}{|c|c|c|c|c|c|c|}
\hline & \multicolumn{3}{|c|}{$100 \mathrm{~km} / \mathrm{h}$} & \multicolumn{3}{c|}{$125 \mathrm{~km} / \mathrm{h}$} \\
\hline & 1. třetina & 2. třetina & 3. třetina & 1. třetina & 2. třetina & 3. třetina \\
\hline $\mathrm{P}$ & 0 & 2 & 0 & 8 & 35 & 4 \\
\hline $\mathrm{B}$ & 1 & 15 & 0 & 1 & 2 & 0 \\
\hline
\end{tabular}

Při zatemnění první třetiny dráhy letu míče byl průměr zásahu hráči při rychlosti $100 \mathrm{~km} / \mathrm{h}-10,95 \mathrm{~cm}$ $(\mathrm{SD}=10,16)$ a při rychlosti $125 \mathrm{~km} / \mathrm{h}$ byl $3,48 \mathrm{~cm}(\mathrm{SD}=6,52)$. Při zatemnění druhé třetiny dráhy letu míče byl průměr u rychlosti $100 \mathrm{~km} / \mathrm{h}-6,87 \mathrm{~cm}(\mathrm{SD}=7,07)$ a u rychlosti $125 \mathrm{~km} / \mathrm{h}-0,02 \mathrm{~cm}(\mathrm{SD}=8,04)$. Při zakrytí třetí třetiny se průměr nacházel při rychlosti $100 \mathrm{~km} / \mathrm{h}$ na $-6,60 \mathrm{~cm}(\mathrm{SD}=6,92)$ a při rychlosti 125 $\mathrm{km} / \mathrm{h}$ na $-3,55 \mathrm{~cm}(\mathrm{SD}=6,73)$.

\section{DISKUSE}

Použití nahrávacího stroje nám umožnilo stabilně nahrávat míče potřebnou rychlostí do dané pozice ve dvorci. Během 10 pokusů za plného vidění nedošlo u žádného účastníka $\mathrm{k}$ časové ani prostorové chybě, všechny míče byly zasaženy a nevyskytla se žádná neobvyklá pozice. I když nahrávací stroj velmi přesně vystřeloval míče, mohou někteří kritici namítat, že hráči byli omezeni reakční dobou, kdy museli reagovat na výstřel míče z nahrávacího stroje, zatímco když podává soupeř, tak přesně vědí, kdy zasáhne míč a kdy vyletí směrem $\mathrm{k}$ nim. Avšak v tomto př́ípadě omezení nemělo vliv na odehrání míče, jelikož účastníci věděli, jakým směrem a kam míč poletí, tudíž odpadl proces reagování na směr míče a rozhodování, zdali se bude muset hrát forhend či bekhend. Rovněž čas letu míče byl dostatečně dlouhý, jelikož maximální rychlosti letu míče byly stanoveny přibližně do $125 \mathrm{~km} / \mathrm{h}$, zatímco v utkáních dosahují míče rychlosti až $200 \mathrm{~km} / \mathrm{h}$.

Výsledky ukázaly, že časové chyby se nejvíce vyskytovaly při zatemnění druhé třetiny dráhy letu míče, což byla fáze během dopadu míče do dvorce. Při nižší rychlosti $100 \mathrm{~km} / \mathrm{h}$ se časové chyby projevovaly př́liš brzkým načasováním úderu, tj. že hráč švihnul raketou dříve, než dorazil míč. Vyskytl se naopak i jeden př́ípad při zatemněné druhé třetině letu míče, že hráč načasoval úder pozdě a švihl raketou př́iliš 
pozdě při této pomalejší rychlosti. Při rychlosti $125 \mathrm{~km} / \mathrm{h}$ se časové chyby projevovaly obvykle pozdním načasováním úderu, kdy hráč švihnul raketou př́liš pozdě. Ovšem vyskytlo se i pár př́ípadů, kdy naopak při této vyšší rychlosti hráč chyboval předčasným švihnutím rakety.

Při zatemnění třetí třetiny dráhy letu míče docházelo pouze k prostorovým chybám. Výsledky ukazují, že př̀i zakrytém vidění během první třetiny dráhy letu míče docházelo k mnohem většímu rozptylu při odehrání míče, zatímco při zakrytí třetí třetiny byl bod odehrání míče téměř shodný. Průměry odehrání míče při zatemnění druhé třetiny dráhy letu míče jsou výrazně zkresleny tím, že u $54 \%$ nahraných míčů s tímto zatemněním se vyskytla časová chyba (míč nebyl zasažen nebo byl zasažen v neobvyklé pozici), a tento průměr vychází ze zbylých úderů.

Tyto výsledky podporují studii Carltona (1981), kde je rovněž důležitá vizuální informace o druhé polovině dráhy letu míče. Nemůžeme však vyvrátit studie, které ŕíkají, že úvodní část dráhy letu míče je nejdůležitější, jelikož jsme $\mathrm{z}$ těchto studií vycházeli a hráči viděli úvodní část dráhy letu míče, aby mohli reagovat. Až po této úvodní fázi docházelo k zatemnění první třetiny dráhy letu míče, která se ukázala oproti našemu předpokladu méně důležitou, než druhá třetina dráhy letu míče, avšak více důležitou, než třetí třetina dráhy letu míče. Na omezení úvodní části dráhy letu míče, tedy ihned po výstřelu míče z nahrávacího stroje, by testovaný hráč reagoval se značným zpožděním, a tento úkol by byl až příliš omezující.

\section{ZÁVĚR}

Hráči potřebují reagovat na úvodní část dráhy letu míče, aby včas určili jeho směr, rychlost a rotaci. Po této úvodní fázi si mohou dovolit nevěnovat takovou pozornost a zaměřit zrak na předpokládané místo dopadu míče ve dvorci. Pro hráče tenisu je podstatná informace nejen o místě dopadu míče ve dvorci, ale i informace o počátku dráhy letu míče po jeho odskoku. Pokud v poslední fázi těsně před kontaktem míče s raketou mají hráči zaujaté správné včasné postavení pro úder, tzn. nemusí míč dobíhat na poslední chvíli, mohou zaměřit vidění na jiné objekty, např. na pohyb či postavení soupeře, a v poslední chvíli tak udělat korekci v následujícím úderu.

Vzhledem $\mathrm{k}$ tomu, že předešlé studie mají různorodé výsledky v této oblasti, je nutné v budoucnu rozdělit výzkum na studie zaměřující se na odhad dráhy letu míče bez jeho dopadu na zem (např. u sportů baseball, softball, badminton, volejbal), s jeho dopadem na zem a následným odrazem, který se vyskytuje u sportů jako je právě tenis, stolní tenis, kriket, a na studie s několikanásobným odrazem u sportů jako je squash, ricochet či podání ve stolním tenise, kde každá změna směru dráhy letu míče může být esenciální pro jeho odhad.

\section{LITERATURA}

ABERNETHY, B., ZAWI, K. Pickup of Kinematics Underpins Expert Perception of Movement Patterns. Journal of Motor Behavior, 2007-39, s. 353-357.

BAHILL, A., T., LaRITZ, T. Why Can't Batters Keep Their Eyes on the Ball? American Scientist, 198472, s. 249-253.

CARLTON, L., G. Processing Visual Feedback Information for Movement Control. Journal of Experimental Psychology: Human Perception and Performance. 1981-7, s. 1019-1030.

CRESPO, M., MILEY, D. Tenisový trenérský manuál 2. stupně: pro vrcholové trenéry. Olomouc: Univerzita Palackého v Olomouci. 2002

CROGNIER, L., FÉRY, Y. Effect of Tactical Initiative on Predicting Passing Shots in Tennis. Applied Cognitive Psychology, 2005-19, s. 637-649.

DAY, L. J. Anticipation in Junior Tennis Players. In Proceedings of International Symposium on Effective Teaching of Racquet sports 1980. Ed. Groppel J., Sears, R. Champaign: University of Illinois.

DELUCIA, P. R., COCHRAN, E. L. Perceptual Information for Batting Can Be Extracted throughout a Ball's Trajectory. Perceptual and Motor Skills. 1985-61, 143-150. 
DESSING, J. C., WIJDENES, L. O., PEPER, E., BEEK, P. J. Adaptations of Lateral Hand Movements to Early And Late Visual Occlusion. Experimental Brain Research. 2009-192, č. 4, s. 669-682.

ELIOT, D., ZUBEREC, S., MILGRAM, P. The Effects of Periodic Visual Occlusion on Ball Catching. Journal of Motor Behaviour. 1994-26, č. 2, s. 113-122.

FÉRY, Y., CROGNIER L. On the Tactical Significance of Game Situations in Anticipating Ball Trajectories in Tennis. Research Quaterly for Exercise and Sport, 2001-72, s. 143-149.

GLENCROSS, D., CIBICH, B. A decision analysis of games skills. Australian Journal of Sports Medicine, 1977-9, s. 72-5.

HALLER, C., F., CLARK, J., E. Effects of Occluding a Ball's Trajectory on the Interception Performance of Adults And Children. Curennt Directions in Motor Development, 1990-3, 80-90.

PORT, N. L., DASSONVILE, D. N. P., GEORGEPOULOS. A. P. Manual Interception of Moving Targets. Experimental Brain Research. 1997-116, č. 3, s. 406-420.

POULTON, E. C. On prediction in skilled movements. Psychological Bulletin, 1957-54, s. 467-78.

RIPPOL, H. Uncertainty and Visual Strategies in Table Tennis. Perceptual and Motor Skills, 1989-68, s. 507-512.

SCHMIDT, R. A. Motor learning and performance; From priciples to practice. Champaign : Human Kinetics. 1991

SHIM, J., CARLTON, L. G., CHOW, J. W., CHAE, W. The Use of Anticipatory Visual Cues by Highly Skilled Tennis Players. Journal of Motor Behavior, 2005a-37, s. 164-175.

SHIM, J., CARLTON, L. G., KWON, Y. Perception of Kinematic Characteristics of Tennis Strokes for Anticipating Stroke Type and Direction. Research Quaterly for Exercise and Sport, 2006-77, s. 326-339.

SHIM, J., MILLER, G., LUTZ, R. Visual Cues and Information Used to Anticipate Tennis Ball Shot and Placement. Journal of Sport Behavior, 2005-28, s. 186-200.

SINGER, N. et al. New Frontiers in Visual Search: An Exploratory Study in Live Tennis Situations. Research Quaterly for Exercise and Sport, 1998-69, s. 290-296.

WILliAMS, A. M., DAVIDS, K., BUROWITZ, L., WILlIAMS, J. G. Visual Search Strategies in Experienced and Inexperienced Soccer Players. Research Quaterly for Exercise and Sport, 1994-65, s. $127-135$.

WILLIAMS, A. M., DAVIDS, K., WILLIAMS, J. G. Visual Perception \& Action in Sport. London: E \& FN Spon. 1999 